\title{
Politics of Programme Accreditation for Quality Assurance in Nigerian Higher Education
}

\author{
Paul Nwakpa \\ Department of Educational Foundations \\ Faculty of Education, Ebonyi State University \\ Abakaliki, Nigeria \\ Email: bropaulnwaoo [AT] gmail.com
}

\begin{abstract}
Quality assurance is an innovation in the educational system. It directs the achievement of goals and revolves around proper, meticulous and timely attention and action on the input-process-output mechanism, by the management. Accreditation of programmes in Nigerian higher education is a means to achieving the desired educational quality in our institutions through the, implementation of government policies by the designated bodies; NUC, NBTE and NCCE. This paper examined the politics of NUC Accreditation of University programmes as an issue of concern in maintaining quality. Politicization of appointments of the head of institutions and lack of uniformity in grading systems were sported as factors militating against quality in higher education. The essence of quality assurance in Nigerian higher institutions was also discussed and necessary suggestions made include, accountability in quality assurance dealings, proper lay down rules and regulations for establishment of private universities and systematic approach to accreditation by NUC and other accreditation bodies.
\end{abstract}

Keywords---- Politics, Programme Accreditation, Quality Assurance and Higher Education

\section{INTRODUCTION}

Political factors have from time to time determined the place of education in ordering the national priorities. It has also shown the degree of faith which Nigeria has in education, as an instrument of change, development and national integration. The growing politicization of education has been an issue of concern in most developing countries and Nigeria is not an exception. Higher education has ceased to be a purely "domesticated organization" whose support is assumed by the public whether or not it demonstrates productivity and efficacy, the recent past and even presently it is witnessing high level of government interest and control as well as increasing intervention by the legislatures and the courts. Also some of the areas .where educational institutions enjoyed autonomy such as, determination of input source, appointment of heads of institutions and resources use have become issues of political or government concern.

The politicization of the appointment of the head of institutions accruing from political instability and incessant change of government has posed a lot of problems to higher education in that most institutions run under administrative factions and anarchy resulting to undesired poor quality output. According to Ofoegbu (2004) politics is the activities involved in getting and using power in public life, and being able to influence decisions that affect a country or a society. Politics is the practice and theory of influencing societal activities and practices. It is the activities of the government, members of law making organizations and political parties and policy formulating bodies. Accreditation programme of the higher education is one of such policies formulated and implemented by the government. Programme accreditation in the higher education is aimed at restoring and maintaining quality to education and the concern for good quality education is what led to the emergence of the quality assurance agencies that conduct performance audit function in the university system through accreditation.

Quality as a concept is a 2Oth century phenomenon that has its needs in the industry and management. Quality became an issue with the advent of industrialization and adoption of new scientific approach to management based on strict division of labour as propounded by F.W. Taylor. Quality implies a certain relative measure against a common standard. This work examines the politics of programme accreditation for quality assurance in Nigerian higher Education. It is good to note here that National University Commission (NUC) is a body in charge of accreditation/quality assurance of Nigerian Universities, the National Board for Technical Education (NBTE) is an agent of Federal Ministry of Education in charge of accreditation/quality assurance of Polytechnics and Colleges of Technology while the National Commission for Colleges of Education (NCCE) accredits and ensures quality in all Colleges of Education in the country.

\section{THE CONCEPT OF HIGHER EDUCATION}

According to Emenalo (2011), Higher education is the largest repositories of certified knowledge of experts in different fields of study needed for the development of the society at large. Higher Education otherwise known as tertiary or post secondary Education consists of Universities, Polytechnics, Colleges of Education. 


\section{THE CONCEPT OF QUALITY ASSURANCE}

Okebukola (2008:24) defined Quality Assurance "as the policies, systems, strategies and resources used by the institution- to satisfy that its quality requirements and standards are being met". It is appropriately described as "Fitness for Purpose". In another way Ojerinde (2008:48) described Quality Assurance as "the degree of conformity of procedures of an organization with set standards." Quality Assurance refers to the systematic activities, implemented in a system so that quality requirements for a service and products are met. In a way quality assurance is to be sure that the right things are done the right way and at the right time.

Quality Assurance and Quality Control are not the same but both are used interchangeably in most organizations. Quality Assurance inspects the process leading to an end while Quality Control controls the process and matches it to the end product. Emenalo (2011) sees Quality Control as more or less a post modem and a retroactive action which only determines the quality of a product or service or system well after processing or production, when wastages or mistakes would have occurred waiting for action or reactions. This calls for an alternative measure of Quality Assurance. The job of a Quality Assurance Agency is to see that organizational standards, processes and policies are in place and also carried out to recommend and implement improvements which must be communicated to stakeholders. Quality Assurance therefore "audits" and or "reviews" and is intended to determine the efficiency of these processes and policies. Quality Assurance assists managers of institutions to plan so that their system can follow certain institutional procedures, goals, events and milestones.

The essence of quality assurance is to ensure that the outcome product of an institution conforms and continues to conform to the controlled procedures and policies. As the system progressed, quality assurance would conduct checkpoints along the way to locate points of cracks and in some cases where it is moving beyond where it has authorization. These would ensure that remedial approaches are adopted at appropriate times. These are the reasons why NUC has put the process of Benchmarking Resource verification. Accreditation (Programme and institutional), Guidelines for admission, Teaching and non teaching staff ratio. Guidelines for facility provision and procurement, Guidelines for the establishment of universities and all others that will enhance the orderly dev elopment of the Nigeria University System (NUS).

For equity, efficiency, effectiveness, relevance and quality, it is important to assure the input, output and process in the university system to fit for the desired purpose. What is the purpose? Fit for the Vision and Mission, fit for the Master Plan Fit for the Strategies Plan and Institutional Goals. The input includes students, teachers, non teaching staff, managers, curriculum, facilities, finance, institutional materials and other resources. These are subjected to processing which includes teaching and learning, research, use of time and space, students services, administration, leadership, community participation and quality control. The output includes skilled and employable graduates, responsible citizens, economic and social development and production of new knowledge. All these are put together to assess the internal efficiency of a university. The higher the internal, efficiency, the higher the level of compliance with best global practices. This is one of the reasons the NUC introduced the concept of institutional accreditation which focuses on all these contents. Whereas, the teaching and learning proactive curriculum, assessment and feedback mechanism, learning environment and learning resources and support systems, the Institutional Accreditation takes a total and global measurement of the university.

The quality assurance activity of the NUC is also exercised in the harmonization of grading system in our universities. A situation where universities grade students based on different point scales does not speak well of our educational system as a nation, (some use the 5 point scale and others 4 point scale). The extent is exemplified by some universities turning out first class graduates with 4 GP while some others graduate first class students with 5 GP. This actually calls for quality harmonization in our universities in order to be well assured of the kind and quality of graduates we are producing as a nation and this will help us to fall in line with the global best practices. Adequate accreditation of Nigerian university programmes and enhanced quality control and assurance is what we need as a nation to help our graduates to be able to have a good fit into purpose in the sphere of life both locally and internationally hence our economic development will definitely be on the fast lane.

\section{WHY WORRY ABOUT QUALITY ASSURANCE}

Every stakeholder in education has every cause to be concerned about quality of education and its assurance. This stems from numerous reasons such as:

(a) Competition: Educational institution being a clientele service organization faces competition among educational institutions for students. With globalization and GATS (Global Agreement on Trade and Services), the educational environment will be seized by competition in order to survive this prevailing situation hence educational institutions need worry shout their quality. The quest to meet the global best practices calls for an effective quality control and assurance in the face of heavy competition among educational institutions as this is considered as the force that attracts students' patronage to any institution.

(b) Customer Satisfaction: Students, parents or sponsoring agencies as customers of educational institutions are now highly conscious of their rights to getting the desired value for their money and time spent. Utility is the driving force that assures students and their various sponsors that their aim(s) of studying in a given institution 
will be actually realized at a predetermined time which will also make them sellable in the labour market. For this reason, they are now demanding good quality teaching and receiving employable skill sets, thus educational institutions should constantly worry about the courses and programmes they run and ensure they are relevant to the needs of the immediate labour market and global environment.

(c) Maintaining Standard: As educational institutions are always concerned about setting own standard and maintaining it continuously year after year. In order to maintain the standard and brace up with the dynamic changes and challenges of the time, the need for quality assurance arises. Institutions should ensure they repeatedly turn out same and better quality graduates as a proof of their steady standard and quality assurance procedures.

(d) Accountability: Every institution is accountable to its stakeholders in terms of the fund (public or private) used on it. Education is funded through tax payers' money and proper accountability is needed to maximize returns on investment by the stakeholders. Thus, quality can be considered a monitoring mechanism.

(e) Improve Employees Morales and Motivation: The quality of an institution will improve the morale and motivation on the staff in performing their duties and responsibilities. If a quality system is in place, the internal processes would be systematic, making every department Complementary to each other's service domain and helping in developing internal customer satisfaction leading to high morale and motivation.

(f) Creditability, Prestige and Status: The consciousness about quality leaves no doubt that continuous quality assurance will bring in credibility to individuals and the institutions concerned and also give room for a consistent organizational development.

(g) Image and Visibility: Image creation is an important attribute of good quality endeavours. Quality institutions have the capacity to attract better stakeholder support like getting merited students from far and near, increased donations/grants from philanthropists, funding agencies and higher-employer interest for her graduates.

\section{NATIONAL UNIVERSITY COMMISSION (NUC) AND ACCREDITATION}

Accreditation according to Nwana (2008) refers to the protocols within the teaching and research programmes of an institution are given the stamp of authenticity by an appropriate authority whether local, national or international. The process of accreditation assumes that any endeavour or discipline has a body of knowledge, skills and attitudes which competent authorities (or recognized authorities) regard as minimum and/or optimum for those who aspire to practice or operate within the endeavour must possess or be seen to possess. This is to be so if they are to receive due recognition from the authorities, the system, or by the society at large within the context of education. Accreditation exercises may be directed at results, certificates and diplomas issued by those institutions. Whether it is directed at institution or at certificates, the goal of accreditation is to assure quality of transaction within the system. Accreditation is sometimes used interchangeably with credibility. However, there is clear difference between them in the sense that credibility may most commonly refer to certificates and diplomas while accreditation refers mostly to courses, programmes and institutions offering them.

The National University Commission has since the early 1990s put in place a system or protocol for accrediting the academic programmes of the universities. The day-to-day implementation of government policies on universities is the responsibility of the National Universities Commission (NUC) which is a parastatal of the federal ministry of education put together for that purpose. NUC visits universities, in order to assess them through the '.Minimum Academic Standard (MAS) which is categorized into three major programmes;

(a) Full accreditation for satisfactory quality. This status may last for five academic programmes subject to a mid-term appraisal every three years.

(b) Interim accreditation for programme with minor deficiencies that could be rectified in less than two academic sessions.

(c) Denied accreditation for unsatisfactory turnout. The university has the right to apply for visitation when the identified deficiencies have been made up. The implication of denied accreditation status or any programme is the loss of credibility coupled with an assumed suspension (NUC Memo 2006, p. 1).

In addition to the establishment of MAS and subject Benchmarks, the NUC also has certain specific procedural guidelines to ensure that an adequate level of quality is attained at inception of new universities or new academic programme through the activities of Standing Committee on Establishment of Private Universities (SCOPU). Other initiatives of the NUC on quality management include the virtual institutes for High Pedagogy (VHEP) that is aimed at the improvement of the quality of teaching and learning in Nigerian Universities; Virtual Library Project to improve the quality of teaching and Research through provision of access to current books, journals and other information resources held by global network of on-line libraries; and the University Annual Review.

Meeting (USARNIS) held annually between the management of each university and NUC at the latter's secretariat.

Thus from the foregoing it could be inferred that both internal and external mechanism are meant to 
enhance quality. However, the rot pervading Nigerian Universities appears to indicate that existing quality management practice is defective. It might be that both the internal and external mechanisms for quality management in the universities are different.

\section{POLITICS OF NUC PROGRAMME ACCREDITATION IN NIGERIA: ISSUES AND CONCERNS}

According to Awe in Babalola and Ayeni (2009), the pre-independence administration based on the recommendation of the Walter Elliot Commission of 1943 established the Inter University Council for Higher Education in the colonies and the University Grant Advisory Committee to advise the British Government on the funding of universities in the colonies.

This might have influenced the decision of the Ashby Commission of 1959 set up by the Federal Government to recommend the establishment of the National Universities Commission in an advisory capacity. The Ashby Commission Report (1961) stipulated that the NUC should play vital part in securing funds for the universities and in distributing them, coordinating (without interfering with) their activities, and in providing cohesion for the, whole system of higher education in the country.

However, subsequent events indicate that the NUC has transformed from an advisory agency to a statutory body performing other functions outside its mandate at inception. Decree No I of 1974 has empowered the NUC to advise the Federal Military Government, through the Federal Commissioner for Education, on certain aspects of higher education, such as development, finance and conditions of all the universities and other degree awarding institutions. Additionally, Emenalo (2011) remarked that through provision of Decree No '16 of 1985, the purpose and mission of universities in Nigeria was given additional meaning. According to her, under Section 10 (ii), the NUC, the Minister of Education and the Head of State of the Federal Military Government have therefore power to lay down minimum standards, accreditation of degrees and other awards of all universities and similar institutions throughout Nigeria and by so doing, the proprietor, as owner and master unmistakably assumed management and other powers which hitherto rested exclusively with the Senate of every university in Nigeria.

From the foregoing, it appears the universities through the empowerment of the NUC have lost their autonomy which is considered sacred for the performance of their basic functions of teaching, research and community service. It was also observed by Ade-Ajayi (2003) that the aim behind the establishment of the NUC was to protect the autonomy of the universities by acting as a buffer institution between the universities and the government especially in matters relating to funding. He added that manipulation of the university system began as soon as the Executive Secretary of the NUC transformed himself into a super Vice Chancellor to tell the Vice-Chancellors what the Military Government on his advice wanted the universities to do.

The use of the Minimum Academic Standard Documents as a benchmark to accredit degree programmes in Nigerian universities has been identified as one of such encroachments on the autonomy and academic freedom of the universities. From the foregoing, it would appear as if the involvement of the National Universities Commission in the quality management function of the Nigerian universities has done more harm than good. The root cause of the negative perception of the universities about the role of the NUC might not be unconnected with the approach of the latter agency to its quality management function through accreditation. This tends to give the impression that universities in Nigeria lack the initiative to maintain quality in their academic functions as well as in the learning environment. The Academic Staff Union of Universities (ASUU) through its National Executive Committee (2005) stated its position in a communiqué on the ongoing accreditation exercise as follow:

$>\quad$ NEC noted that the accreditation exercise has its history in the steady decay of universities resulting from under funding, steady subversion of the powers of the university Senate by successive government since the 1980s and the failure of the controllers of the universities to defend the powers of Senate and the integrity of the universities.

D ASUU has always held that accreditation of degrees and academic programmes should be left to professional bodies empowered to regulate professional education and training or chartered learned societies and associations or to a Universities Accreditation Committee specifically constituted by the Universities themselves for the purpose of accreditation.

D ASUU has several times called on the Federal Government to establish a Visitation Panel for the NUC to examine the present role of the NUC in the context of the law establishing it, to assess its finances, accountability and administration in the institution, which has played such an extensive role in the university system. The perception of the universities tends to indicate that the procedure for its quality management functions is more of inspection rather than supervision. This appears to be correct against the background of the advisory role that the NUC was meant to play at inception before the advent of the military administration. Perhaps it is necessary at this point to clarify the concepts of inspection and supervision. 
According to Igwe (2001), to inspect means to find fault and to ascertain that all is in line .with expected standard while supervision means to direct, to oversee, to guide and to make sure that the expected standards are being met. Thus it appears that supervision rather than inspection is what Nigerian universities need. This is partly what informs the observation ${ }^{\wedge}$ made by Akinkugbe (2001) that the idea of a nationally agreed set of minimum standards for the nation's universities is good, though not an inevitable one. Besides, where such explicit formulations are considered necessary, care must be taken to express them in more abstract terms than virtually handing down syllabuses to the university. An institution that is incapable of designing its own curricula and syllabuses and being constantly innovative about them does not deserve the title of a university.

The primary responsibility of the universities for quality assurance through internal mechanisms is encapsulated in the remark of Olumike (2012) that the university community must surely be one of the first to engage in self-assessment, self criticism, and self-improvement, through review of courses and modification of curricula). He added that no organization outside the universities is better placed than the university itself to undertake the performance audit. However, it is ironic that such a statement came from someone whose tenure witnessed an accelerated erosion of university autonomy and impingement of the academic freedom of Nigerian universities. However, the establishment of buffer institutions like the NUC the world over has been attributed to the following reasons: to avoid a government decision-making monopoly in the organization, to have a more comprehensive representative of the society in decisions related to education and to relieve the learning institutions from their dependency on governments. These parastatals, occasionally referred to as buffer institutions (Adeyemi 2013), or intermediary bodies' (Tomosope, 2013) are established as corporate bodies to organize, promote, supervise and control education services for the benefit of the people. They usually enjoy considerable autonomy from federal government by law or constitutional provision (Glenny and Dalglish, 2011). The forms of educational parastatals vary greatly particularly among the states depending on the state's unique history, the personalities and geo-political relationships.

However, they are viewed as levers in steering and coordinating the education system. They are the mediums of injecting a degree of sensitivity into the organization towards the attainment of educational objectives. Experience in the Nigerian university system indicates that rather than be a facilitator of events, the NUC is perceived as government megaphone, which has been accused of unnecessarily lengthening the lines of management that is contrary to modern management literature (Ofoegbu, 2004). Thus, Ade-Ajayi (2003) observed that the NUC could not be reformed, as it has become a federal parastatal, subordinate to the Federal Ministry of Education. He then suggested that the Ministry is over burdened and a new Ministry more used to advising than supervising and directing the universities should be put in place. In order to sanitize the universities, Ade-Ajayi suggested that the NUC must revert to its traditional role at inception, which is that of an advisory function.

\section{CONCLUSION}

Quality of higher education and the need for effective quality assurance mechanisms beyond those of institutions themselves are becoming priority themes in national strategies for higher education. This is driven by the importance attached to higher education as a driver of growth and in achieving the millennium development goals (MDGs), on one hand and the emergence of new types of higher education providers (beyond public institutions) on the other. At the institutional level, increasing demand for accountability by governments, other founders and the public, coupled with the desire to be comparable with the best in country and internationally is pushing higher education institution to pay more attention to quality assurance system. Accreditation of universities by NUC in Nigeria and other accreditation bodies for higher education in Nigeria needs to be systematized. And some bottle neck nested for us to save our higher education. Nigerian certificate as asserted by Nwana (2008) has lost its worth in the international world. Therefore all hands must be on deck to remedy the situation. The government, Politicians, Law makers, policy formulators, NUC and other accreditation bodies, higher institutions, students and parents and all stakeholders in education should ail be involved to guarantee quality for our higher education.

\section{RECOMMENDATIONS}

As a way forward, the following recommendations will go a long way in ameliorating the decaying state and assure quality in our Higher Education.

$\checkmark \quad$ The government arid its agencies responsible for accreditation of higher institutions should be more accountable to the quality assurance dealings.

$\checkmark \quad$ There should be proper lay down regulations for establishment and accreditation of other higher education providers apart from public institutions.

$\checkmark \quad$ There should be a systematic approach by NUC and other accreditation bodies for higher Education; if quality must be restored and maintained.

$\checkmark \quad$ University autonomy should be maintained in practice not only in policy.

$\checkmark \quad$ NUC should review the grading system of universities and make it uniform, not some using 5 points scale while others 4 point scale. It does not assure quality. 


\section{REFERENCES}

- Ade-Ajayi, J.F. (2003), Position paper presented at the University Stakeholders National Consultative Forum. Federal Ministry of Education. Abuja. March; 1-4.

- Adeyemi D.G (2013) Nigeria Education Proposals for a voyage the year 2020. RE Publishers Ltd Lagos.

- Akinkugbe, O.O. (2001), The Challenges of Quality Public Education in Nigeria. Research Journal of Education Studies, 4(1); 2-6, March.

- Babalola, J. B. \& Ayeni, A. D. (2009). Educational Management: Theories and Tasks. Macmillan Publishers Nigeria Limited.

- Emenalo, F. C. (2011). Improving the Quality of Inputs in Higher Education. Journal of Women Academia. (JOWA) 2 (2).

- Glenny, L.A. \& Dalgish, T.K. (2011). Public Universities, State Agencies and the Law: Constitutional Autonomy in Decline, Berkley, C.A., Centre for Research and Development in Higher Education, the University of California.

- Igwe C.K (2001) Professional growth and development in Education, Research Journal of Education Studies $8(5) 53-66$.

- NUC (2006). Result of the November, 2005 System Wide Accreditation on Exercise, Monday memo 5 (3).

- Nwana. O. C. (2008). University Academics in Nigeria; Being Memoirs of an Insider. Peacewise Publishers Owerri.

- Ofoegbu, F. I. (2004). Agencies, Boards and Commissions in the Nigerian Education System. In: Nwagwu, N.A., Ijeoma, M.E and C. C. Nwagwu (ed.) Organization and Administration of Education: Perspective and Practices, Festa Press limited Benin City.

- Ojerinde, D. (2008), "Quality Assurance in Nigerian University System, Assessment and Feedback Mechanism" in Proceedings of a Symposium Organized by the Federal University of Technology Akure Nigeria; $4^{\text {th }}$ November, 2008, pp. 19-46

- Okebukola, P. (2008). "Quality Assurance in Nigeria University System, Role of Stakeholders" in Proceedings of a Symposium Organized by the Federal University of Technology, Akure, 4 Nov. 2008 pp. 10-18

- Olumike, F.C (2012) Report on Policy Plans and Implementation strategies. Oyo University of Ibadan Printing Press.

- Tomosope, T. K. (2011). Management of the universities in Nigeria: A Look at the past, the present and the future. In Resource Management in the University System, Proceedings of the NUC. CVC/BC International Seminar Zaria. 